\title{
Perfect and Possessive Structures in Irish and Russian
}

\author{
VIKTOR BAYDA
}

\section{Introduction}

The present article has two main objectives. First of, all it aims to introduce Slavonic data into the discussion of the Irish perfect. As the perfect is a category which is not often used by the literati who have been the only source of written evidence on language history for centuries, its development remains concealed to a considerable extent. This lack of diachronic data leads us to hypothetical reconstructions. The Russian literary and dialectal perfect forms may provide some evidence as to how a similar structure may have also developed in Irish. Certain explanations of the Russian form could thus be equally applicable to the making of the Irish perfect. Presenting these explanations and the ways of applying them to the Irish perfect forms the second objective of the article.

\section{Be-languages vs. have-languages}

1.1 One of the linguistic features that both Irish and Russian share is the fact that they are both so called be-languages as opposed to have-languages according to the classification suggested by A. V. Isatsenko (1974). Belanguages express the meaning of possession by using a construction of the type 'mihi est' or 'est apud me' - both based on the verb 'to be'. However have-languages use a specialised possessive verb for this case (cf. in English 'to have'). In fact Russian does have a verb with the meaning 'to have' - 'иметь', which in fact is borrowed from Old-Church-Slavonic it appears to be highly limited in use. Irish hasn't got such a verb at all. Thus for the phrase 'X has a dog' the Irish and Russian equivalents would be respectively (1) and (2).
(1) Tá madra ag $X$
(2) $\quad y \quad X-a$
(есть) собака is $a \operatorname{dog}$ at $\mathrm{X}$
at X.GEN
(is) ${ }^{1} \quad$ a dog

It seems reasonable to characterise the two different ways of encoding possession as using a Possessive Verb (hereinafter PV) (e.g. English 'have', French 'avoir', Chinese 'yǒu' etc.) or a Possessive Construction

In Russian the verb 'to be' is usually omitted in the present. 
(hereinafter PC) (e.g. Latin [NP.DAT + esse], Finnish [NP.ADESSIV + olla ('to be')], Japanese [NP(-ni)-wa (theme) + aru/iru 'to be'] etc.).

1.2 Structures with perfect meaning both in Irish and Russian, as the case often is in different languages, use the notion of possession to express the agent obliquely: the possessor thus being the subject or the one who 'possesses' the result of the previous action. Cf. the following examples:
(3) Tá sé déanta ag $X$ is it done at $\mathrm{X}$

'He has done it'
(4) $\quad y \quad X-a$ at X.GEN it done

'He has done it'

In literary Russian this structure is of extremely limited use. In some dialects of the North-West, however, it is a standard way of expressing perfect meaning, which brings it closer to the Irish perfect not only in formation but also in function. The fact that possession is used to make perfects is by no means strange and has been discussed on numerous occasions. The basis for such formations is the metaphoric realisation of the agent as the possessor of the result of a previous action.

\section{Possessive perfect forms in Slavonic}

2.1.1 In Old-Slavonic we find an essive perfect which is formed by combining the verb 'to be' with the past participle active in $-l$. The participle was active and therefore there were no restrictions as to which verbs could or could not have a participle. Thus the perfect too could be formed using any verb - transitive or intransitive. This formed a good basis for the development of the perfect into a simple past tense in West- and EastSlavonic languages ousting the aorist - the original simple past. The South-Slavonic languages still retain the old verbal system with the aorist and the perfect with the participle in $-l$.

2.1.2 Possessive perfect forms are not unknown in Slavonic languages. However they are mostly confined to the dialects. Macedonian is the only Slavonic language where a possessive perfect has entered the literary standard. ${ }^{2}$ These perfects can be derived from both transitive and intransitive verbs. A PV is used combined with the - $n-/-t$ - past participle passive which normally agrees in gender and number with the object. In the case of

\footnotetext{
It should be noted, however, that some (especially Bulgarian) linguists do not consider Macedonian a language, but a dialect of Bulgarian.
} 
intransitive verbs the participle can rather be called pseudo-passive, not passive and takes the fixed impersonal form ending in $-o$.

Czech:

(5) Mám úlohu napsanou have-I task.SING.ACC write.PAST.PART.PASS.FEM.SING.ACC 'I have written the task'

(6) Mám zatopleno have-I heat (the oven). PAST.PART.PASS.IMPERS

'I have heated the oven'

Bulgarian:

(7) Имам черно на бяло записано have-I black on white write.PAST.PART.PASS.IMPERS

'I have written (it) in black and white'

Macedonian:

(8) Имаат бегано have-they run.PAST.PART.PASS.IMPERS

'They have run/ They ran. / They were running'

(9) Имам дојдено have-I come.PAST.PART.PASS.IMPERS

'I have come / I came'

(10) Јас сум дојден

I be.PRES.1SING come.PAST.PART.(PSEUDO-)PASS.MASC.SING.

'I have come / I came'

As the last example shows, the verb 'to be' can also be used to form the perfect with intransitive verbs (Cf. French 'je suis venu', German 'ich bin gekommen', Dutch 'ik ben gekomen'). In all these languages a PV is used. Russian, however, just like Irish, is a be-language and therefore expresses possession naturally with a PC, not a PV. Compare (1) and (2) which we had above in 1.1 both meaning ' $\mathrm{X}$ has a dog'.
(1) Tá madra ag $X$
(2) $\quad y \quad X-a$ (есть) собака is $a \operatorname{dog}$ at $\mathrm{X}$ at X.GEN
(is) $\quad \mathrm{a} \operatorname{dog}$

2.1.3 (11) is a typical example of the possessive resultative perfect that can be used in standard colloquial Russian. 
(11) У меня посуда уже вымыта $и$ обед приготовлен At I.GEN dishes already wash. and lunch prepare.

$$
\begin{aligned}
& \text { P.P.P.FEM.SG P.P.P.M.SG } \\
& \text { P.S. }
\end{aligned}
$$

'I have already washed the dishes and cooked the lunch'

There are certain restrictions for forming a possessive resultative in standard colloquial Russian. First, the semantic object has to be present in the structure encoded as the syntactic subject (nосудa and обед in (13)). Second, the possession can be brought down to real or metaphoric possession. Third, only transitive verbs can take part in these structures.

2.1.4 If we now look at the data presented from the dialects of the NorthWest of Russia we will see that these restrictions do not work here.

(12) У кошки уже стащена рыбина At cat.GEN already filch.PAST.PART.PASS.FEM.SG fish

'The cat has already filched the fish'

(13) вчерась $y$ меня наволочка сложена $u$ положена yesterday at I.GEN pillowcase fold.P.P.PASS.F.SG and put. P.P.PASS.F.SG

'I folded and put the pillowcase (there) yesterday'

(14) $y$ меня сын еще ни разу не сфотографирован At I.GEN son yet never not photograph.PAST.PART.PASS.MASC.SG 'I haven't ever made a photo of my son before'

The following examples present the 'objectless' type.

(15) Сколько у вас дано за нее? How much at you.GEN give.PAST.PART.PASS.IMPERS for she.ACC 'How much did you pay for it?'

(16) У кого это на скатерти налито? At who.GEN PART on table cloth.LOC spill.PAST.PART.PASS.IMPERS 'And who has spilt on the table cloth?'
(17) У меня забыто а Степанида помнит
At I.GEN forget.PAST.PART. and/but Stepanida remember.PRES PASS.IMPERS

'I have forgotten (it) but Stepanida (still) remembers'

There are also no restrictions on the use of intransitive verbs. 
(18) У них $\quad$ в город At they.GEN in town.ACC

'They have gone to town'

(19) Tym y трактора here at tractor

'A tractor has passed here' уехано

leave.PAST.PART.PASS.IMPERS

\section{The perfect construction in Irish}

3.1 In Irish three types of perfect are normally pointed out.

1 The normal type Tá sé déanta agam 'I have done it'

2 The objectless type Tá labhartha agam leis 'I have spoken to him' (impers. use of tá) Tá glaoite ag an gcoileach 'The cock has crowed'

3 The intransitive type Tá sé imithe 'He has gone'

For detailed discussion of these types see Ó Sé (1994: 46-52).

3.2 The first two types have thus exact equivalents in Russian dialectal perfect types. It is also interesting to note that in the grammar of Na Bráithre Críostaí the objectless type is called 'the impersonal use of tá', and this has an equivalent in Russian which uses an impersonal form of the participle in the same case and for the same purpose. The main difference between the two languages lies in the intransitive type. Russian still applies the possessive way of expressing perfect meaning being unable to make the participle give up its passive characteristics whereas Irish succeeds in releasing the participle of the voice opposition and forms the intransitive type with the verb 'to be' on its own (thus showing the same pattern as in French il est venu and Dutch hij is gekomen).

3.3 The perfect construction as we know it today can't have developed in Old Irish as its two elements - the possessive construction and the verbal adjective (the participle) $)^{3}$ could not naturally appear in the same sentence: the former used the substantive verb whereas the latter could be used as a predicate only with the copula as any other adjective. Later the substantive verb expanded its use to situations where it earlier could not appear including sentences with a predicative adjective. This made possible a collocation of the verbal adjective and the possessive marker within the same clause. The perfect construction could have developed on the basis

\footnotetext{
For a discussion of the terms 'verbal adjective' vs. 'participle' see Greene (1971: 130-137).
} 
of the resultative construction by bringing the resultant state into the agent's sphere. The possessive agent marker 'ag X' (together with the substantive verb) was in this case not just a marker but the 'embodiment', the actual realisation of bringing the action into the agent's domain. This possessive 'packaging' of the original resultative form most probably became the trigger of the shift in meaning from resultative to perfect thus causing the movement of the construction en route of development into a perfect: the constant expression of the agent as the volitional stimulus to action raised the actionality of the construction as a whole and violated one of the conditions of the resultative form - non-agentivity. The construction was brought closer to the form characteristic of a perfect - in the situation all the same participants were expressed as in the original structure.

3.4 The development of the perfect can hardly be observed in the sources on the history of Irish. In the early texts there is no evidence of the existence of the construction Tá sé déanta agam. Even the instances we find in Early Modern Irish texts are not perfects but merely resultatives with an oblique possessive agent encoding. Perfects are in general not natural in literary narrative texts. The fact that the possessive perfect construction wasn't attested in Early Modern Irish texts is certainly due to the stylistic conservatism of the contemporary authors. Scribes and authors of the pre-nineteenthcentury period would not use colloquial forms of language, preferring to apply the older literary register. In the seventeenth century Rudimenta Grammaticae Hibernicae the following is said of the construction: saepe dicitur atá Brian buailte, sed hoc reprobatur a peritis (Greene 1971: 136). Only after the fall of the older register could colloquial language find its way into written texts. The construction became more manifest in later texts, when the literary language lost its status and the dialects came to light. The two subjectless types (cf. Tá glaoite ag an gcoileach and Tá labhartha agam leis) have no precedence whatsoever. This can, at least partly, be due to the same matter of subjectivity. A vivid illustration of this can be presented by the situation with the Russian perfect: only the transitive type with certain restrictions is acceptable whereas the other types failed to enter the literary language at all and retained their dialectal status. This could give us a clue to what could have occurred from the Early Modern Irish period onwards. The various perfect structures could 
therefore be older than is usually presumed, being used in common speech, but failing to enter the more formal register.

3.5.0 It seems reasonable to point out that when considering modern Irish a difference should be made between a construction like Tá sé déanta which is a resultative, and thus could be described as having passive characteristics not only syntactically, but also in its semantics (compare Stenson 1981, where it is called a Passive form) and Tá sé déanta aige which should be characterised as a perfect with predominant resultative meaning (having passive characteristics only syntactically or structurally). 3.5.1 The possessive form of the perfect is in keeping with the typological peculiarities of Irish as Irish tends to clearly demonstrate a difference in encoding dynamic actions and states (Ó Corráin 1997: 168-171; 2001: 170). In the case of the latter the subject of the action is usually encoded as an oblique object, whereas in the centre of the structure various nominative and periphrastic constructions take place. As the semantics of state is central both for the resultative and for the perfect, the possessive (or, structurally oblique-objective) encoding of the subject of the previous action, in the light of the above mentioned peculiarities of the Irish language, is yet another case in which the features of the Irish predicative system become manifest.

3.5.2 The status of the preposition 'ag' has been much discussed in works on the Irish perfect. Two main views have been proposed with 'ag' being considered either a possessive or an agentive marker. In fact, 'ag' can be called agentive to the same extent as, for example, the genitive in 'teacht an bhuachalla' (lit. 'coming of the boy') can be called an agentive marker. It cannot avoid marking the agent and thus having at least some agentive meaning, but this meaning is purely additional or even forced by the prototypical possessive meaning. The fact that the preposition 'ag' is a possessive and not an agentive marker is well seen if we consider the passive. Violating the rules of contemporary Irish slightly one could use prepositions 'le' or 'ó' with a passive to express the agent. Consider the following examples from De Bhaldraithe (1985): Múineadh ó tháilliúr maith é. 'He was taught by a good tailor'; Ar dionadh ó shiuiinéra é? 'Was it covered by the carpenter?' The possessive marker ag cannot be used here. It should be noted however that 'ó' is also quite often used for marking the agent of the verbal adjective (De Bhaldraithe 1985: 199). 
3.5.3.1 The intriguing question is whether the possessive form of the perfect in Irish and Russian evolved as a result of adding the possessor to a resultative construction as it has been outlined above or the whole construction emerged simultaneously which would imply that it wasn't the resultative Tá sé déanta that formed the base, but that Tá sé déanta agam evolved on its own, independently, as a different use of the verbal adjective and having a different meaning from the very beginning (in this case for instance, 'ag X' acted not as a 'trigger' pushing the basic resultative to more active perfect meaning but as an original, basic element). This question is even more important for the 'non-prototypical' types of the Irish perfect like Tá glaoite ag an gcoileach and Tá labhartha agam leis both of which lack the most important element of any resultative, i.e. the patient encoded as a syntactic subject.

3.5.3.2 The Irish perfect and possessive constructions have been extensively compared to similar constructions in French, German and, of course, English - languages which use PVs, not PCs as Russian and Irish do. ${ }^{4}$ Special attention to the Russian construction was first drawn by Yurij Maslov in 1949. He wrote that the special value of the Russian construction is that in it the inner notion of possession is more vivid, more obvious than in the have-periphrasis. He argued also that the notion of possession which lies at the base of this type of constructions cannot be brought down to real or metaphoric possession, but should be understood in a much wider sense, maybe as certain interest of the person in the action or in its results, or as positioning of the action in the agent's domain etc. The greater vividness of these inner notions is by no means an obstacle for creating grammatically subjectless structures. Maslov draws a conclusion: "Doesn't this mean that the notion that forms the basis of the constructions in question - exactly because it wasn't a notion of mere possession - could freely combine with the absence of the subject itself and even with intransitiveness?" (Maslov 1984 (1949): 241-242). This conclusion of a much wider interpretation of the notion of possession when applied to perfect forms as of "positioning of the action in the agent's domain", or even simply of "some kind of identification of the action with the agent" can be exemplified by the following Irish and Russian sentences in which no resultative forms are used.

\footnotetext{
4 Irish and Russian material has been compared in Orr 1989, which unfortunately I could not take into account not having access to it when preparing the present article.
} 
(20) Tá tinneas cinn orm agaibh

Is pain head.Gen on-me at-you

'You give me a headache'

(21) $О н$ у меня всё сделает

$\mathrm{He}$ at I.Gen everything do.Fut

'I shall make him do everything'

3.5.4 A conclusion can thus be made that the various types of perfect structures (Tá sé déanta agam, Tá glaoite ag an gcoileach and Tá labhartha agam leis) united under the notion of possessive ownership of action in general could possibly be created spontaneously, simultaneously, not by way of the spread of the perfect notion from the first type to the others. Possession was used spontaneously as a tool most appropriate for expressing the kind of meaning in question, for connecting the state and the agent. These different models may thus have originated as constructions built (a) (concerning time relativity) spontaneously, simultaneously and (b) (concerning function and semantics) in order to bring the action (or result of the action, as the resultative model was actually used) into the subject's domain, that is in order to identify the action, or the result of the action with its subject. This could form an alternative view on the development of the Irish perfect to that outlined in 3.1 above.

\section{Conclusion: comparison of Irish and Russian perfect structures}

4.1.1 Change from one form of possessive expression to another implies not only the change itself but involves a large part of the whole system in restructuring. Meanings that previously could be expressed by a PC can't be expressed by a PV because there meaning cannot coincide with the active semantics of a verb. It may be for example the Middle voice meanings that are lost. At the same time the 'verbness' of possessive expression gives new opportunities for involving this $\mathrm{PV}$ in encoding other, new meanings (cf. have dinner, have a sleep, have a rest, use of have in the Continuous).

4.1.2 The fact that both Irish and Russian perfect structures use the construction with the preposition 'at', and not a verb like 'to have' for the

\footnotetext{
5 A further example could be Bhios i ngrá le Rosy agus fáinne ar a méar agam (Jenkinson 2000: 124) (lit. 'I was in love with Rosy and a ring on her finger at me' or 'I was in love with Rose, me having a ring on her finger').
} 
formation of a perfect suggests that these structures should be analysed in the broader context of all cases when 'something/somebody is/are at somebody else'. At the same rate the English have-perfect should be analysed within the context of other structures that involve this verb.

4.1.3 A PC is naturally more stative in meaning, whereas a PV is more active/motional. The latter makes the whole situation of possession active because of its form. On the other hand the situation of possession described by a PC must have slightly different semantics. The possessor of the action/result has a less prominent position in the PC-like encoding. In a statement with a PV the possessor is an overt and obvious agent.

4.1.4 A PV is more abstract. It abstracts possession to the field of actions which already is a very abstract category in itself. What is encoded as an action needn't actually be one. But once encoded as an action it becomes realised or 'felt' as one. It can then be used in new ways, giving rise to new opportunities which are later quite naturally realised. Encoding possession as a locative construction gives a different effect. It connects the PC with other locative constructions, involving different kinds of side-meanings to the notion of possession. Neither way of encoding possession can therefore be called ultimate. The encoding is built up in the field of other similarly structured forms which automatically makes them subject to semantic reanalysis and adapting to one of the chosen encoding systems. The process is thus shuttle-like: the possession encoding evolves on the base of certain language elements being affected by them. Afterwards the possessive form produces a counter-effect influencing the structures which once lay at its base by extrapolating some of its semantics onto them.

4.2 The way of encoding possessive meaning determines not only the system of possessive expressions proper but also a wider context of language elements, quite possibly having a significant impact on the system as a whole and in that way bringing in certain typological implications. From this point of view Irish and Russian present unique evidence for a study of typological consequences in languages using a possessive verb or a possessive construction.

Moscow State University 
VIKTOR BAYDA

\title{
SUMMARY
}

\section{ВИКТОР БАЙДА}

\section{ПЕРФЕКТНЫЕ И ПОСЕССИВНЫЕ КОНСТРУКЦИИ В ИРЛАНДСКОМ И РУССКОМ ЯЗЫКАХ}

\begin{abstract}
НАСТОЯЩАЯ СТАТЬЯ ИМЕЕТ ДВЕ ОСНОВНЫЕ ЦЕЛИ. ВО-ПЕРВЫХ, ПРЕДСТАВИТЬ МАТЕРИАЛ СЛАВЯНСКИХ ЯЗЫКОВ, КОТОРЫЙ МОГ БЫ БЫТЬ ИСПОЛЬЗОВАН В ОБСУЖДЕНИИ ПЕРФЕКТА В ИРЛАНДСКОМ ЯЗЫКЕ. ПОСКОЛЬКУ ПЕРФЕКТ ОТНОСИТСЯ К ТЕМ ГР АММАТИЧЕСКИМ КАТЕГОР ИЯМ, КОТОРЫЕ НЕ ВСЕГДА СТАНОВЯТСЯ ФАКТОМ ЯЗЫКА АВТОРОВ РУКОПИСЕЙ - ЕДИНСТВЕННОГО ИСТОЧНИКА ДАННЫХ ПО ИСТОР ИИ ЯЗЫКА - ПАР АЛЛЕЛЬНО СВОЕМУ Р АЗВИТИЮ В РЕАЛЬНОМ ЯЗЫКЕ, НАБЛЮДЕНИЕ ЭТОГО РАЗВИТИЯ ОКАЗЫВАЕТСЯ В ЗНАЧИТЕЛЬНОЙ СТЕПЕНИ ЗАТРУДНЕНО. ОТСУТСТВИЕ ДОСТАТОЧНОГО КОЛИЧЕСТВА ДАННЫХ ПО ДИАХР ОНИИ ПР ИВОДИТ К ГИПОТЕТИЧЕСКИМ РЕКОНСТРУКЦИЯМ. ПЕРФЕКТНЫЕ ФОРМЫ В РУССКОМ ЛИТЕРАТУРНОМ ЯЗЫКЕ И В ДИАЛЕКТАХ МОГУТ ПРОЛИТЬ СВЕТ НА ТО, КАК ПОХОЖАЯ КОНСТРУКЦИЯ МОГЛА Р АЗВИВАТЬСЯ В ИРЛАНДСКОМ ЯЗЫКЕ. НЕКОТОРЫЕ ИЗ ПРЕДЛАГАЕМЫХ ОБЪЯСНЕНИЙ КАСАТЕЛЬНО ПЕРФЕКТНЫХ ФОРМ В РУССКОМ ЯЗЫКЕ МОГУТ БЫТЬ РАВНОВЕРОЯТНЫ И В ОТНОШЕНИИ ФОРМИР ОВАНИЯ ИРЛАНДСКОГО ПЕРФЕКТА. ПРЕДСТАВИТЬ ЭТИ ОБЪЯСНЕНИЯ И ТО, КАК ИХ МОЖНО БЫЛО БЫ ПР ИЛОЖИТЬ К ИР ЛАНДСКОМУ МАТЕР ИАЛУ, СОСТАВЛЯЕТ ВТОРУЮ ЦЕЛЬ ДАННОЙ СТАТЬИ.
\end{abstract}

